\title{
Kecacingan usus pada anak sekolah dasar di Tanawangko Kecamatan Tombariri Kabupaten Minahasa
}

\author{
${ }^{1}$ Renjer Luis \\ ${ }^{2}$ Josef S. B. Tuda \\ ${ }^{2}$ Angle Sorisi
}

\author{
${ }^{1}$ Kandidat Skripsi Fakultas Kedokteran Universitas Sam Ratulangi Manado \\ ${ }^{2}$ Bagian Parasitologi Fakultas Kedokteran Universitas Sam Ratulangi Manado \\ Email: renjerluis12235@gmail.com
}

\begin{abstract}
Helminth is one of the most commonly infected parasites in human. According to WHO, more than 1,5 billions of people around the world are infected by helminthes. The highest number of helminthiasis cases is of school age children. This study was aimed to obtain the helminthiasis cases in students of elementary schools at Tanawangko Minahasa and to identify the types of helmiths. This was a descriptive study. Feces samples from the students were kept in feces pot and then were examined microscopically. The results showed that of the 118 feces samples there were five samples (4.3\%) which were positively infected by helminth, Ascaris lumbricoides.
\end{abstract}

Keywords: helminths, student of elementary school

\begin{abstract}
Abstrak: Cacing usus merupakan salah satu parasit yang paling banyak menginfeksi manusia. WHO mencatat lebih dari 1,5 miliar orang di seluruh dunia terinfeksi cacing usus dengan angka tertinggi terjadi pada usia anak sekolah. Penelitian ini bertujuan untuk mengetahui kecacingan usus pada murid sekolah dasar di Tanawangko Kecamatan Tombariri Kabupaten Minahasa dan juga mengidentifikasi jenis cacing usus yang menginfeksi. Jenis penelitian ini ialah survei deskriptif. Pengambilan sampel feses menggunakan pot feses yang diberikan kepada murid-murid dan dilakukan pemeriksaan mikroskopik. Hasil penelitian memperlihatkan bahwa dari 118 pot yang dikembalikan didapatkan hasil 5 murid $(4,3 \%)$ yang terinfeksi cacing usus. Jenis cacing yang ditemukan ialah Ascaris lumbricoides dari kelima murid tersebut.
\end{abstract}

Kata kunci: kecacingan usus, anak sekolah dasar

Parasit cacing yang menginfeksi manusia terbagi dalam dua filum yaitu platyhelminthes dan nemathelminthes, dan dalam pengelompokannya terbagi lagi atas tiga kelas yaitu pada platyhelminthes terdapat cestoda dan trematoda, sedangkan pada nemathelminthes terdapat kelas nematoda. ${ }^{1}$ Spesies cacing yang paling sering menginfeksi manusia masuk dalam kelas nematoda dengan penularan tersering melalui tanah (soil transmitted helminths), termasuk di dalamnya yaitu cacing gelang (Ascaris lumbricoides), cacing cambuk
(Trichuris trichiura), dan cacing tambang (Necator americanus dan Ancylostoma duodenale). ${ }^{2}$ Parasit cacing yang menginfeksi manusia paling sering pada usus manusia yang merupakan tempat yang baik untuk berkembang biak dan juga terdapat banyak makanan untuk kelangsungan hidup cacing; oleh karena itu disebut cacing usus. ${ }^{3}$ Cacing usus menginfeksi tersering pada orang yang memiliki kebersihan dan sanitasi yang buruk, terutama anak-anak yang kurang memiliki pemahaman cara hidup bersih dan 
sehat. Selain itu kepadatan antar tempat tinggal penduduk, kondisi geografis, serta iklim berperan penting dalam penularan cacing usus tersebut. ${ }^{4}$

Laporan WHO pada tahun 2012 menunjukkan lebih dari 1,5 miliar orang atau sekitar $24 \%$ populasi manusia di dunia terinfeksi cacing usus ini. Infeksi ini tersebar luas pada area beriklim tropis dan subtropis dengan angka tersering di sub sahara Afrika, Amerika, Tiongkok, dan Asia Timur. Sekitar 240 juta anak pra sekolah dan lebih dari 600 juta anak umur sekolah di area dimana parasit ini menular secara intensif. ${ }^{5}$ Infeksi cacing usus tersebar luas di pedesaan maupun perkotaan dengan jenis cacing tersering yaitu Ascaris lumbricoides mencapai 8071.121 juta orang, Trichuris trichiura mencapai 604-795 juta, dan cacing tambang mencapai 576-740 juta di dunia. ${ }^{6}$

Prevalensi di Indonesia masih cukup tinggi yaitu sekitar $60-70 \%$. Hal tersebut disebabkan iklim tropis, tingginya kelembaban udara serta sanitasi dan higiene masyarakat yang buruk. Kebiasaan hidup yang kurang sehat seperti buang air besar sembarangan, berjalan tanpa alas kaki, serta makan tanpa mencuci tangan membuat penularan cacing usus semakin parah. Serta pengetahuan tentang bahayanya infeksi cacing usus masih cukup jarang di masyarakat. ${ }^{4,7}$ Berdasarkan data dari Dinas Kesehatan Provinsi Sulawesi Utara, prevalensi kecacingan pada tahun 2010 yaitu sebesar 13,6\%. Penelitian di Desa Teling Kecamatan Tombariri Kabupaten Minahasa pada tahun 2012 didapatkan infeksi cacing usus sebesar 12,2\% yang terdiri dari infeksi Ascaris lumbricoides dan Ancylostoma duodenale sebesar 36,4\%. Trichuris trichiura sebesar 9\% dan Oxyrus vermicularis sebesar $18,2 \%{ }^{8}$

Tujuan penelitian ini ialah untuk mengetahui dan mengidentifikasi cacing yang menginfeksi pada anak sekolah dasar di Tanawangko. Pertimbangan dipilihnya Tanawangko karena pada survei sebelum penelitian didapatkan kondisi geografis yang letaknya di pinggir pantai serta kepadatan antar rumah penduduknya yang memungkinkan penularan cacing usus dengan baik. Selain itu banyaknya anakanak yang bermain dan berkontak langsung dengan tanah serta jarang memakai alas kaki, juga masih banyak penduduk yang belum mempunyai toilet dan buang air besar sembarangan yang memperburuk penularan cacing usus.

\section{METODE PENELITIAN}

Jenis penelitian ini ialah survei deskriptif. Penelitian ini dilakukan di empat sekolah dasar yang berada di wilayah Tanawangko yaitu: SD Inpres Tambala, SD GMIM Sarani Matani, SDN 1 Tanawangko, dan SDN 2 Tanawangko sejak bulan Desember 2015 hingga Januari 2016. Subjek penelitian yaitu siswa kelas I sampai kelas 6; semuanya diberikan pot feses untuk pengambilan sampel. Pot feses diberi identitas usia, jenis kelamin, dan nama siswa. Sampel feses diperiksa di Laboratorium Parasitologi Fakultas Kedokteran Universitas Sam Ratulangi Manado menggunakan teknik pemeriksaan langsung tinja. Data hasil pemeriksaan diolah dalam bentuk tabel frekuensi dan ditampilkan dalam persentase.

\section{HASIL PENELITIAN}

Tanawangko merupakan daerah pesisir pantai yang memiliki empat desa yaitu desa Tambala, Sarani Matani, Borgo, dan Ranowangko. Tanawangko terletak di Kecamatan Tombariri, di sebelah Utara dan Barat berbatasan dengan Laut Sulawesi, sebelah Timur dengan Kecamatan Pineleng, dan sebelah Selatan dengan Kota Tomohon. Tanawangko memiliki tanah yang gembur dan berpasir sehingga telur cacing dapat berkembang dengan baik. Jarak antar rumah penduduk satu dengan yang lain tergolong padat; selain itu masih banyak rumah yang belum memiliki jamban dan akses air bersih masih tergolong buruk. Masyarakat serta anakanak di Tanawangko masih banyak yang mempunyai kebiasaan buang air besar di sungai dan laut serta tidak mencuci tangan dengan sabun setelah tiba dirumah. Hal ini dapat memperburuk infeksi dari cacing 
usus yang ditularkan lewat feces karena higiene yang kurang baik.

Pada penelitian di Tanawangko pada bulan Desember 2015 hingga Januari 2016 terhadap anak sekolah dasar kelas I-VI dari empat sekolah didapatkan total sampel feses yang terkumpul sebanyak 118 pot dan diperiksa di Laboratorium Parasitologi Fakultas Kedokteran Universitas Sam Ratulangi Manado (Tabel 1 dan 2).

Tabel 1. Hasil pemeriksaan telur cacing

\begin{tabular}{lcc}
\hline Sekolah & N & Positif \\
\hline SD Inpres Tambala & 33 & 3 \\
SD GMIM Sarani Matani & 19 & 0 \\
SDN 1 Tanawangko & 25 & 2 \\
SDN 2 Tanawangko & 41 & 0 \\
Jumlah & 118 & 5 \\
\hline
\end{tabular}

Tabel 2. Identifikasi jenis cacing

\begin{tabular}{lcc}
\hline Jenis cacing & N & $\%$ \\
\hline Ascaris lumbricoides & 5 & 100 \\
Trichuris trichiura & 0 & 0 \\
Ancylostoma duodenale & 0 & 0 \\
Necator americanus & 0 & 0 \\
Jumlah & 5 & 100 \\
\hline
\end{tabular}

\section{BAHASAN}

Pada penelitian mengenai kecacingan usus pada anak sekolah dasar di Tanawangko terdapat sebanyak 118 pot sampel yang dikembalikan. Pot sampel yang tidak dikembalikan karena berbagai alasan seperti tidak merasa buang air besar, jijik, pot sampel hilang, dan malu membawa sampel. Berdasarkan hasil pemeriksaan didapatkan jenis telur cacing Ascaris lumbricoides yang dibuahi dan tidak dibuahi. Sampel positif telur cacing tersebut terdapat tiga sampel dari SD Inpres Tambala dan dua sampel dari SDN 1 Tanawangko. Dari hasil pengolahan data hasil pemeriksaan didapatkan positif cacing sebanyak $5(4,3 \%)$. Hasil pemeriksaan tersebut dibandingkan dengan data penelitian sebelumnya oleh $\mathrm{Nusa}^{7}$ di SD YPK Imanuel Akas, penelitian oleh Kundaian et al. ${ }^{8}$ di SD GMIM 85 dan SD Katolik Desa Wori tahun 2010, dan penelitian yang dilakukan oleh Tangel et al. ${ }^{9}$ di SD GMIM 85 Wori dan SD Katolik
Desa Wori tahun 2015. Penelitian di SD YPK Imanuel Akas diperoleh hasil sebanyak $15(22,7 \%)$ sampel positif mengandung cacing dengan adanya telur Ascaris lumbricoides sebanyak 11 (16,6\%) dan yang mengandung telur Trichuris trichiura sebanyak $4(6,1 \%){ }^{7}$ Penelitian di SD GMIM 85 dan SD Katolik Desa Wori tahun 2010 diperoleh 20 (12\%) sampel yang positif cacing dengan adanya telur Ankylostoma duodenale sebanyak 12 (7\%), telur cacing Ascaris lumbricoides sebanyak 5 (3\%), dan yang mengandung Trichuris trichiura sebanyak 3 (2\%). Hal ini menunjukan bahwa angka infeksi cacing di SD Inpres Tambala, SD GMIM Sarani Matani, SDN 1 Tanawangko, dan SDN 2 Tanawangko lebih rendah daripada penelitian di daerah lain. Rendahnya infeksi cacing tersebut karena dugaan kebersihan anak-anak lebih baik dari penelitian sebelumnya, dan juga puskesmas telah memberikan obat cacing pada bulan Agustus 2015 atau tiga bulan sebelum penelitian ini dilakukan.

\section{SIMPULAN}

Dari hasil penelitian tentang kecacingan usus pada anak sekolah dasar di Tanawangko dapat disimpulkan bahwa:

1. Sebanyak tiga siswa positif cacing usus di SD Inpres Tambala dan dua siswa positif cacing usus di SDN 1 Tanawangko dengan jumlah total sebanyak 5 (4,3\%) dari seluruh sampel.

2. Jenis cacing yang teridentifikasi yaitu Ascaris lumbricoides dari semua sampel positif.

\section{SARAN}

Infeksi cacing usus dapat menimbulkan dampak seperti gangguan nutrisi serta gangguan perkembangan anak yang berakibat kualitas belajar menurun. Pencegahan serta pengobatan perlu dilakukan untuk mengurangi jumlah kecacingan usus pada anak-anak.

\section{DAFTAR PUSTAKA}

1. Paniker CK, Sougata G. Paniker's Textbook of Medical Parasitology. New Delhi: 
Jaypee Brothers Medical Publisher Ltd, 2013.

2. WHO. Soil transmitted helminthiases. [Online] [Cited: 2016 Oct 10]. Available from: http://www.who.int/ gho/neglected_diseases/soil_transmitte d_helminthiases/en/.

3. Rampengan TH. Ankilostomiasis. Penyakit Infeksi Tropik pada Anak (2nd ed). Jakarta: EGC, 2008; p. 226.

4. Zulkoni A. Helminth. Parasitologi. Yogyakarta: Nuha Medika, 2011; p. 64, 65.

5. CDC. Soil-transmitted helminths. [Online] [Cited: 2016 Oct 9]. Available from: http://www.cdc.gov/parasites/sth/.

6. WHO. Soil transmitted helminths. [Online] 2016. [Cited: 2016 Oct 10]. Available from: http://www.who.int/ mediacentre/ factsheet/fs366/en/.

7. Nusa LA, Umboh JML, Pijoh VD. Hubungan antara higiene perorangan dengan infestasi cacing usus pada siswa
SD Yayasan Pendidikan Imanuel Akas Kecamatan Damau Kabupaten Talaud. [Online] 2013. [Cited: 2016 Oct 8]. Available from: http://fkm.unsrat.ac.id/wp-content/ uploads/2013/11/listra-jurnal.pdf.

8. Kundaian F, Umboh JML, Kepel BJ. Hubungan antara sanitasi lingkungan dengan infestasi cacing pada murid sekolah dasar di Desa Teling Kecamatan Tombariri Kabupaten Minahasa. [Online]. 2012. [Cited: 2016 Oct 9]. Available from: http://ejournal.unsrat.ac.id/index.php/ke smas/article/download/80/76.

9. Tangel F, Tuda JSB, Pijoh V. Infeksi parasit usus pada anak sekolah dasar di pesisir pantai Kecamatan Wori Kabupaten Minahasa. [Online] Januari 2016. [Cited: Oktober 9, 2016.] Available from:

http://ejournal.unsrat.ac.id/index.php/eb iomedik/article/view/10838/10427. 1. 